\title{
Strategy Implementation Traceability of Breeding Shrimp Business in Indonesia
}

\author{
Angky Soedrijanto (Corresponding author) \\ Faculty of Fisheries and Marine Science, Brawijaya University, Indonesia \\ E-mail: agustitantu@yahoo.com
}

Martani Huseini

Faculty of Social and Politics Science University of Indonesia (Co-promote 2), Indonesia

\begin{abstract}
Margono Setiawan
Faculty of Economic and Business Brawijaya University (Co-promote 1), Indonesia
\end{abstract}

Eddy Suprayitno

Faculty of Fisheries and Marine Science Brawijaya University (Promotor), Indonesia

Received: January 24, 2013 Accepted: February 5, 2013 Published: February 28, 2013

doi:10.5296/jas.v1i1.3334 URL: http://dx.doi.org/10.5296/jas.v1i1.3334

\begin{abstract}
Broodstock in the preparation of the document traceability from sea to table is upstream of all the problems in the shrimp business in Indonesia. Until now there has been no regulation or standard of Good Breeding Practices Operaional procedures that are technically capable of guaranteeing the treatment of antibiotics free. The research aims to identify, locate and establish a starting point in the implementation of traceability Indonesian shrimp from hatchery business. Analyzing the performance of the business associated with breeding success in the implementation of traceability as well as find the implementation strategy of Indonesia's shrimp traceability. The results showed that tracer code to recording the capture area of the broodstock and technically seeding practices is importance. Application numeric code that registered would be included in the memorandum of sale of seed should be done
\end{abstract}


jointly by the Government and the Association of hatchery. Standards and sanctions, can be implemented by the supplier, and cold storage. Supplier has the right to buy at the local market price for non-tracer prawn; so that cold storage have to refuse shrimp if nothing to seed sales without a memorandum of traceability. Based on these simple sales memorandum format, traceability could have been implemented for accurate searching. The reflects code of location tracer hatchery / backyard in District / City + catcher + spawner + breeder + seed brokers whole or in part. Technicians and Managers responsible for the source of information if cases of food safety incidents, For accounting purposes of the company, that buyers have a recording data search to find a farmer or even seed traders. In the event that a broodstock shrimp business comes from imports, the tracer code catcher broodstock and breeder may contain information search origin imported interpreted code or code numbers importers import documents.

Keywords: Broodstock, Hatchery, Traceability

\section{Background}

Tiger shrimp (Penaeus monodon Fabricius) is a 'native shrimp' Indonesia. Activities: arrest broodstock, captive breeding to produce seed until shrimp are cultured in Indonesia basically produce shrimp first derivative or F1. Broodstock tiger shrimp in Indonesia has been standardized in SNI 01-6142-2006 namely Penaeus monodon Fabricius 1798 (Anonymous, 2008. Nurdjana, 2008).

Vannamei shrimp (Litopenaeus vannamei), comes from the waters of the Pacific Ocean in the Hawaiian Islands and the West coast of America; making broodstock go to Indonesia is the first derivative of $\mathrm{F} 1$ from crosses or natural broodstock at the hatchery on the islands of Hawaii. Therefore, vannamei shrimp cultivated in Indonesia as F1 is essentially a second-generation seed or F2.

Regulation of the Minister of Marine and Fisheries Phone PER.03/MEN/2005 about quarantine measures by third parties; articles 2, 3 and 4 require careful monitoring. Articles 6, 7 and 8 as a form of action that can be taken by the Government with no third-party oversight of technical rules. In addition, the Minister of Marine and Fisheries Number PER.15/MEN/2011 on Quality Control and Safety of Fishery The Log into the Territory of the Republic of Indonesia. Article 6 (paragraph 2) - there is no requirement of integrity pact as a form of full responsibility importer which states that: if the imported fish is detected as carriers of disease or potentially harmful to the spread of disease will be immediately destroyed instantly, including all losses are borne by the importer. There is also no form of supervision by an independent party to quarantine the fish (which comes from imports) is. Whereas the broodstock in the preparation of the document traceability from sea to table is upstream of all the problems in the shrimp business in Indonesia.

Businesses seeding states that that there is no regulation or standard of Good Breeding Practices Operaional procedure is technically capable of guaranteeing free treatment of antibiotics. Hatchery since 2004 have begun to consciously change the way seed movement by abandoning the use of antibiotics and to promote the use of probiotics. 
Possible use of antibiotics banned in the backyard hatchery or very likely to occur in:

(1) Phase sterilization of sea water; great potential against malpractices such as the use of antibiotics is prohibited Decree No.20/2003 and the Marine and Fisheries Council Directive 96/23/EC.

(2) Phase vannamei shrimps local broodstock acceptance comes from the cultivation in ponds is likely to be carrier of disease, bacteria and viruses that can infect the other broodstock or the eggs and larvae.

(3) Perceptions of the prediction error results shrimp eggs and larvae, due to not knowing kinship broodstock shrimp.

(4) Phase promotion. A large difference in the perception of farmers (buyers) often force pembenih promoting seed using certain stimulants.

(5) Phase transportation. The possible use of anti-bacterial chemicals, stimulants and endurance enhancer seed during transportation.

Shrimp seed sector performance is also faced with the problem of productivity. Broodstock shrimp eggs hatch capable of producing between 50,000 until 1 million head, while holding vannamei shrimp eggs hatch only able to produce between 50,000 until 150, 000 pieces. Based on these facts required number of broodstock vannamei shrimp which is more than the broodstock shrimp to produce the same amount of eggs (Dahuri, 2004. Nurdjana, 2008).

Initiation document tracer on seeding in accordance with Article 5 point e the Minister of Marine Affairs and Fisheries No.. 15 of 2011. Documents tracer in the form of a memorandum is a form of concrete technical implementation seeding was implemented GBP.

Broodstock shrimp obtained from the interception at sea 'could have been' derived from hatchery seed salvage disposal proceeds. Bad habits backyard hatcheries and spawning in the cleaning bath is a 'drain' and throwing flushed water its contents into the sea. Assumptions need seeds, broodstock based shrimp production target Indonesia following exchange potentials appear in Table 1.

Table 1. Assumptions Shrimp seed needs, broodstock and target production shrimp indonesia

\begin{tabular}{|c|c|c|c|c|c|c|c|c|}
\hline & \multirow{2}{*}{ Unit } & \multicolumn{2}{|c|}{ ASUMPTION 1} & \multirow{2}{*}{$\begin{array}{c}\text { ASUMPTION } \\
2 \\
\text { Vannamei } \\
\end{array}$} & \multirow{2}{*}{$\begin{array}{c}\text { ASUMPTION } \\
3 \\
\text { Vannamei } \\
\end{array}$} & \multirow{2}{*}{$\begin{array}{c}\text { ASUMPTION } \\
4 \\
\text { Vannamei } \\
\end{array}$} & \multirow{2}{*}{$\begin{array}{c}\text { ASUMPTION } \\
5 \\
\text { Vannamei } \\
\end{array}$} & \multirow{2}{*}{$\begin{array}{c}\text { ASUMPTION } \\
6 \\
\text { Vannamei } \\
\end{array}$} \\
\hline & & Tiger Shrimp & Vannamei & & & & & \\
\hline $\begin{array}{l}\text { Production } \\
\text { target }\end{array}$ & Ton & 50.000 & 450.000 & 450.000 & 450.000 & 450.000 & 450.000 & 450.000 \\
\hline \multicolumn{9}{|l|}{$\begin{array}{l}\text { ASUMPTION } \\
\text { FACTS }\end{array}$} \\
\hline Size (HOSO) & Pcs/kg & 50 & 60 & 70 & 60 & 70 & 60 & 70 \\
\hline $\begin{array}{l}\text { Weight per } \\
\text { piece }\end{array}$ & Gram & 20 & 16,67 & 14,29 & 16,67 & 14,29 & 16,67 & 14,29 \\
\hline Average SR & $\%$ & 20 & 70 & 70 & 60 & 60 & 50 & 50 \\
\hline $\begin{array}{ll}\begin{array}{l}\text { Need seed } \\
\text { healthy }\end{array} & \end{array}$ & piece & 12.500 .000 .000 & 38.571.428.571 & 45 milyar & 45 milyar & 52,5 milyar & 54 milyar & 63 milyar \\
\hline
\end{tabular}




\begin{tabular}{|l|l|r|r|r|r|r|r|r|}
\hline $\begin{array}{l}\text { Eggs per } \\
\text { broodstock }\end{array}$ & Pcs & 250.000 & 50.000 & 50.000 & 50.000 & 50.000 & 50.000 & 50.000 \\
\hline \% eggs hatch & $\%$ & 50 & 40 & 40 & 40 & 40 & 40 & 40 \\
\hline $\begin{array}{l}\text { Need a healthy } \\
\text { broodstock }\end{array}$ & Pcs & $\mathbf{1 0 0 . 0 0 0}$ & $\mathbf{1 . 9 2 8 . 5 7 1}$ & $\mathbf{2 . 2 5 0 . 0 0 0}$ & $\mathbf{2 . 2 5 0 . 0 0 0}$ & $\mathbf{2 . 6 2 5 . 0 0 0}$ & $\mathbf{2 . 7 0 0 . 0 0 0}$ & $\mathbf{3 . 1 5 0 . 0 0 0}$ \\
\hline $\begin{array}{l}\text { Origin } \\
\text { broodstock }\end{array}$ & Lokal & Impor & Impor & Impor & Impor & Impor & Impor \\
\hline
\end{tabular}

\begin{tabular}{|c|c|c|c|}
\hline $\begin{array}{l}\text { HOSO } \\
\text { product value }\end{array}$ & $\mathrm{Rp}$ & 2,5 trilyun & 18 trilyun \\
\hline $\begin{array}{l}\text { Potential } \\
\text { devisa }\end{array}$ & $\mathbf{R p}$ & & 20,5 trilyun \\
\hline \multicolumn{4}{|l|}{$\begin{array}{ll}\begin{array}{l}\text { Added value } \\
\text { export }\end{array} \\
\end{array}$} \\
\hline Head Less & Ton & 31.500 & 297.000 \\
\hline $\begin{array}{ll}\mathrm{HL} & \text { price } \\
\text { export } & \end{array}$ & $\$ / k g$ & 10,50 & 8,90 \\
\hline \multicolumn{2}{|r|}{ Rp/kg } & 94.500 & 80.100 \\
\hline Devisa HL & $\mathrm{Rp}$ & 4,725 trilyun & 36,045 trilyun \\
\hline $\begin{array}{l}\text { Total devisa } \\
\text { HL }\end{array}$ & $\mathbf{R p}$ & & 40,770 trilyun \\
\hline
\end{tabular}

Source: Analysis data, (2012)

\section{Purposes}

1. Identify, locate and establish a starting point in the implementation of traceability Indonesian shrimp hatchery business.

2. Analyzing the performance of the business associated with potential breeding success in the implementation of traceability.

3. Finding a form of strategy implementation in simple Indonesian shrimp traceability.

\section{Methodology}

Steps to find traceability implementation strategy using SWOT matrix analysis techniques BSC (Strength Weakness Opportunity Threath - Balanced Score Card) through the following steps:

1. Based on established research questionnaires five (5) priority in the implementation of traceability appropriate strategy titles and research purposes.

2. Establish 5 (five) priority as basic assumptions systematically arranged by serial number; then later be formulated Strength, Weakness, Opportunity and Threath systematically into the SWOT matrix.

3. Each formulation SWOT given scores. Delivery techniques based on Balanced Score Cards scores were set assuming achievement that should (rated 100 on a scale of $0 \mathrm{~s} / \mathrm{d} 100$ ) compared with the facts. Description Strength and Opportunity considered positive, while the description of Weakness and Threath judged negatively.

4. Based on the compilation of a negative positive value at every stage of the matrix obtained five (5) a brief description of the form of traceability implementation strategy. Compilation of scores is a priority, which is the highest scores form the most important step in the strategy implementation. 


\section{Result and Discussion}

Business of shrimp in fact involve many businesses at every stage. Each stage has a HACCP that must be considered by the business itself because of the potential occurrence of irregularities in the system of quality assurance of food safety (food safety) should be recorded in the document search (traceability). Facts that show high potential for seedling deviation form made active use of antibiotics can be seen in the distribution of illicit drugs in the vicinity of the farm shop seeding.

Based on these empirical facts, the five basic assumptions to find strategies for implementing traceability in the seeding is:

Table 2. Basic Assumptions

\begin{tabular}{|c|l|l|}
\hline $\begin{array}{c}\text { Basic } \\
\text { assumption }\end{array}$ & \multicolumn{1}{|c|}{ Tiger shrimp } & \multicolumn{1}{|c|}{ Vannamei shrimp } \\
\hline 1 & Experience hatchery sector actors & Experience hatchery sector actors \\
\hline 2 & Kinship tiger shrimp broodstock & Kinship vannamei shrimp broodstock \\
\hline 3 & $\begin{array}{l}\text { Scientific aspects of practical / theoretical } \\
\text { breeder }\end{array}$ & Aspect of the available of broodstock \\
\hline 4 & Sustainability of production towards seed & Facts broodstock towards seed production \\
\hline 5 & Brocess \\
\hline
\end{tabular}

Table 3. BSC SWOT Analysis of Broodstock and Tiger Shrimp Seed / Black Tiger Shrimp

\begin{tabular}{|c|c|c|c|c|c|c|c|c|}
\hline & & FA & STRENGHT & SCORE & WEAKNESS & SCORE & & \\
\hline & & 1 & $\begin{array}{l}\text { Actors shrimp } \\
\text { hatcheries have } \\
\text { specific expertises }\end{array}$ & 90 & $\begin{array}{l}\text { Lack of knowledge and } \\
\text { skills enhancement }\end{array}$ & -60 & & \\
\hline & & 2 & $\begin{array}{l}\text { Each actor has a clear } \\
\text { record of the origin of } \\
\text { the broodstock }\end{array}$ & 90 & $\begin{array}{l}\text { No quantitative } \\
\text { analysis of kinship } \\
\text { (DNA code) }\end{array}$ & -70 & & \\
\hline & & 3 & $\begin{array}{l}\text { Breeder know and } \\
\text { recognize each } \\
\text { broodstock is crossed }\end{array}$ & 80 & $\begin{array}{l}\text { Egg quality is not all } \\
\text { good }\end{array}$ & -70 & & \\
\hline & & 4 & $\begin{array}{l}\text { Broodstock is always } \\
\text { available either locally } \\
\text { or imported }\end{array}$ & 90 & $\begin{array}{l}\text { The size and quality of } \\
\text { the broodstock is not } \\
\text { always as desired }\end{array}$ & -60 & & \\
\hline & & 5 & $\begin{array}{l}\text { Price and supply } \\
\text { mains to pembenih } \\
\text { relatively stable }\end{array}$ & 90 & $\begin{array}{l}\text { Catcher broodstock } \\
\text { stem mere collector } \\
\text { shrimp }\end{array}$ & -70 & & \\
\hline FA & OPPORTUNITY & SCORE & STRATEGY S-O & SCORE & STRATEGY W-O & SCORE & $\begin{array}{l}\text { COMPILATION } \\
\text { SWO STRATEGY }\end{array}$ & SCORE \\
\hline 1 & $\begin{array}{l}\text { Spawning failure can } \\
\text { always be / able to be } \\
\text { minimized }\end{array}$ & 50 & $\begin{array}{l}\text { Need to continue } \\
\text { efforts to increase egg } \\
\text { production }\end{array}$ & 140 & $\begin{array}{l}\text { Need to increase skills } \\
\text { for the better }\end{array}$ & -10 & $\begin{array}{l}\text { Skills training for } \\
\text { breeder }\end{array}$ & 130 \\
\hline 2 & $\begin{array}{l}\text { Avoid any possibility } \\
\text { of inbreeding }\end{array}$ & 70 & $\begin{array}{l}\text { Keep the } \\
\text { identification of } \\
\text { kinship applicative }\end{array}$ & 160 & $\begin{array}{l}\text { Need for government } \\
\text { facilitation means of } \\
\text { identification }\end{array}$ & 0 & $\begin{array}{l}\text { Procurement means of } \\
\text { identification at the } \\
\text { Aquaculture Center } \\
\text { nearest }\end{array}$ & 160 \\
\hline 3 & $\begin{array}{l}\text { Breeder can predict } \\
\text { better / proper quantity }\end{array}$ & 80 & $\begin{array}{lr}\text { Breeder } & \text { have } \\
\text { consistently } & \text { recorded }\end{array}$ & 160 & $\begin{array}{l}\text { breeder noted the } \\
\text { quality of eggs from }\end{array}$ & 10 & $\begin{array}{l}\text { Awareness of the } \\
\text { importance of quality }\end{array}$ & 170 \\
\hline
\end{tabular}




\begin{tabular}{|c|c|c|c|c|c|c|c|c|}
\hline & of eggs & & the cross & & crosses & & and kinship broodstock & \\
\hline 4 & $\begin{array}{l}\text { Seed production can } \\
\text { take place at any time } \\
\text { desired }\end{array}$ & 90 & $\begin{array}{l}\text { Keep in quality } \\
\text { improvement efforts, } \\
\text { the broodstock }\end{array}$ & 180 & $\begin{array}{l}\text { Encourage breeders to } \\
\text { send only good } \\
\text { broodstock }\end{array}$ & 30 & $\begin{array}{l}\text { Socialization quality } \\
\text { and handling host for } \\
\text { breeder }\end{array}$ & 210 \\
\hline 5 & $\begin{array}{l}\text { Breeder to selecting a } \\
\text { good quality mains }\end{array}$ & 90 & $\begin{array}{l}\text { Incentives for } \\
\text { breeders who produce } \\
\text { quality } \\
\text { broodstock }\end{array}$ & 180 & $\begin{array}{l}\text { Improved knowledge } \\
\text { of the quality of the } \\
\text { broodstock for breeder }\end{array}$ & 20 & $\begin{array}{l}\text { Creating quality } \\
\text { standardization } \\
\text { broodstock and prices }\end{array}$ & 200 \\
\hline FA & THREATH & SCORE & STRATEGY S-T & SCORE & STRATEGY W-T & SCORE & $\begin{array}{l}\text { COMPILATION } \\
\text { SWT STRATEGY }\end{array}$ & SCORE \\
\hline 1 & $\begin{array}{l}\text { Confidence high } \\
\text { breeder often careless }\end{array}$ & -70 & $\begin{array}{lr}\text { Need understanding } \\
\text { of } & \text { quality } \\
\text { management } & \text { for } \\
\text { breeder } & \\
\end{array}$ & 20 & $\begin{array}{lr}\begin{array}{l}\text { Need to } \\
\text { performance }\end{array} & \text { train } \\
\text { good } \\
\text { breeding } \\
\text { applicable }\end{array}$ & -130 & $\begin{array}{l}\text { Applying recording in } \\
\text { good breeding practices }\end{array}$ & -110 \\
\hline 2 & $\begin{array}{l}\text { Equipment and / or the } \\
\text { cost of holding } \\
\text { expensive } \\
\text { analysis }\end{array}$ & -70 & $\begin{array}{l}\text { Need for government } \\
\text { facilitation means of } \\
\text { identification }\end{array}$ & 20 & $\begin{array}{l}\text { Keep subsidy cost } \\
\text { analysis of kinship } \\
\text { broodstock }\end{array}$ & -140 & $\begin{array}{l}\text { Broodstock always } \\
\text { selected kinship = } \\
\text { recorded }\end{array}$ & -120 \\
\hline 3 & $\begin{array}{l}\text { Breeder perform a } \\
\text { variety of ways to } \\
\text { seed 'good' }\end{array}$ & -80 & $\begin{array}{lr}\text { Keep in } \\
\text { understanding long } \\
\text { term business strategy } \\
\text { for breeder }\end{array}$ & 0 & $\begin{array}{l}\text { Need technical } \\
\text { understanding to avoid } \\
\text { malpractice }\end{array}$ & -150 & $\begin{array}{l}\text { Maintain commitment } \\
\text { and consistency of } \\
\text { work spawner }\end{array}$ & -150 \\
\hline 4 & $\begin{array}{l}\text { Fertility broodstock is } \\
\text { no guarantee of } \\
\text { 'natural' }\end{array}$ & - & $\begin{array}{lr}\text { Need } & \text { for } \\
\text { standardization } & \text { and } \\
\text { certification } & \text { of } \\
\text { carrier-grade } & \\
\end{array}$ & 0 & $\begin{array}{l}\text { Strengthen } \\
\text { understanding about } \\
\text { the quality of the } \\
\text { broodstock breeder }\end{array}$ & -150 & $\begin{array}{l}\text { breeder commitment in } \\
\text { determining the quality } \\
\text { of the broodstock }\end{array}$ & -150 \\
\hline 5 & $\begin{array}{l}\text { Treatment catcher / } \\
\text { breeder many } \\
\text { engineering }\end{array}$ & -90 & $\begin{array}{l}\text { Strengthening } \\
\text { business ethics of the } \\
\text { breeder broodstock }\end{array}$ & 0 & $\begin{array}{l}\text { Providing knowledge } \\
\text { to the breeder seed }\end{array}$ & -160 & $\begin{array}{l}\text { Breeder's commitment } \\
\text { to supply a good } \\
\text { broodstock }\end{array}$ & -160 \\
\hline & & & $\begin{array}{l}\text { COMPILATION } \\
\text { SOT STRATEGY }\end{array}$ & SCORE & $\begin{array}{l}\text { COMPILATION } \\
\text { WOT STRATEGY }\end{array}$ & SCORE & SWOT STRATEGY & SCORE \\
\hline & & & $\begin{array}{l}\text { breeder commitment } \\
\text { and consistent record } \\
\text { breed process }\end{array}$ & 160 & $\begin{array}{l}\text { Skills offset by the } \\
\text { implementation of } \\
\text { quality systems }\end{array}$ & -140 & $\begin{array}{l}\text { Storing data track } \\
\text { record of spawning }\end{array}$ & 40 \\
\hline & & & $\begin{array}{l}\text { Certificate of kinship } \\
\text { is the basis of } \\
\text { traceability }\end{array}$ & 180 & $\begin{array}{l}\text { Facilitation and DNA } \\
\text { analysis subsidy = } \\
\text { ensure quality seed }\end{array}$ & -140 & $\begin{array}{l}\text { The broodstock must } \\
\text { be certified origin } \\
\text { (COO) }\end{array}$ & 80 \\
\hline & & & $\begin{array}{l}\text { breeder reported pijah } \\
\text { process in writing } \\
\text { (form) }\end{array}$ & 160 & $\begin{array}{l}\text { Commitment and } \\
\text { consistency in } \\
\text { recording (for tracer) }\end{array}$ & -140 & $\begin{array}{l}\text { The publication of the } \\
\text { data tracer seed by } \\
\text { breeder }\end{array}$ & 40 \\
\hline & & & $\begin{array}{l}\text { breeder issued } \\
\text { integrity seed quality }\end{array}$ & 180 & $\begin{array}{l}\text { Broodstock selection } \\
\text { for spawning to be } \\
\text { precise }\end{array}$ & -120 & $\begin{array}{l}\text { Building a search the } \\
\text { data security system } \\
\text { origin master }\end{array}$ & 120 \\
\hline & & & $\begin{array}{l}\text { broodstock receiving } \\
\text { system at the hatchery } \\
\text { should be strictly }\end{array}$ & 180 & $\begin{array}{l}\text { Strengthen } \\
\text { understanding of } \\
\text { quality to seed for } \\
\text { breeder }\end{array}$ & -140 & $\begin{array}{l}\text { Determination of } \\
\text { price incentives seed } \\
\text { from the } \\
\text { broodstock-grade }\end{array}$ & 80 \\
\hline
\end{tabular}

Table 4. BSC SWOT Analysis of Broodstock and Seed Vannamei Shrimp

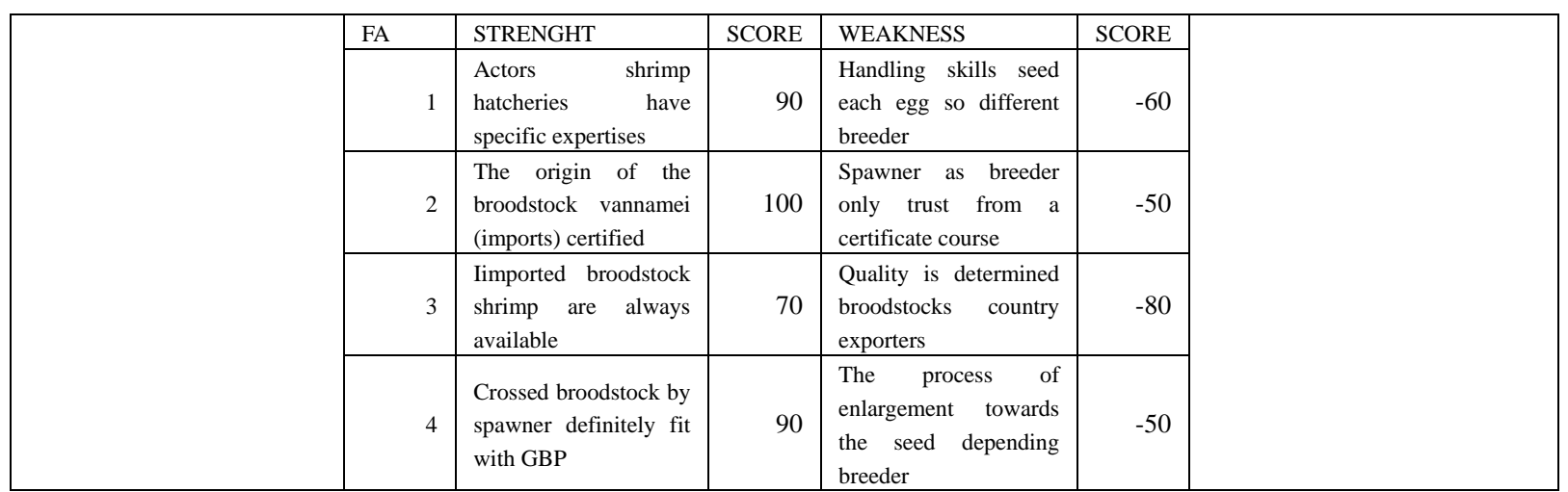




\begin{tabular}{|c|c|c|c|c|c|c|c|c|}
\hline & & 5 & $\begin{array}{l}\text { Eggs from importers } \\
\text { spawn always of high } \\
\text { quality }\end{array}$ & 90 & $\begin{array}{l}\text { Spawner alone bear } \\
\text { spawning failure }\end{array}$ & -50 & & \\
\hline FA & OPPORTUNITY & SCORE & STRATEGY S-O & SCORE & STRATEGY W-O & SCORE & $\begin{array}{l}\text { COMPILATION } \\
\text { STRATEGY SWO }\end{array}$ & SCORE \\
\hline 1 & 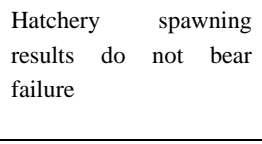 & 90 & $\begin{array}{l}\text { Strengthening the } \\
\text { performance of } \\
\text { enlargement eggs into } \\
\text { seed }\end{array}$ & 180 & $\begin{array}{l}\text { Need to increase skills } \\
\text { for the better }\end{array}$ & 30 & $\begin{array}{l}\text { Skills training for } \\
\text { breeder }\end{array}$ & 210 \\
\hline 2 & $\begin{array}{l}\text { Kinship broodstock } \\
\text { clearly written imports } \\
\text { its DNA code }\end{array}$ & 100 & $\begin{array}{l}\text { Need precision } \\
\text { observe broodstock if } \\
\text { appropriate documents }\end{array}$ & 200 & $\begin{array}{l}\text { Need precision observe } \\
\text { broodstock if } \\
\text { appropriate documents }\end{array}$ & 50 & $\begin{array}{l}\text { Training continued to } \\
\text { recognize the quality } \\
\text { of a good broodstock }\end{array}$ & 250 \\
\hline 3 & $\begin{array}{l}\text { Broodstock vannamei } \\
\text { easily import process }\end{array}$ & 80 & $\begin{array}{l}\text { Imports should always } \\
\text { pay attention to } \\
\text { grammar while } \\
\text { cultivating }\end{array}$ & 150 & $\begin{array}{l}\text { Breeder keep a record / } \\
\text { document the origin of } \\
\text { the broodstock }\end{array}$ & 0 & $\begin{array}{l}\text { The introduction of } \\
\text { traceability until } \\
\text { towards seed }\end{array}$ & 150 \\
\hline 4 & $\begin{array}{l}\text { Egg production results } \\
\text { according to the theory } \\
\text { of hatchery spawning }\end{array}$ & 90 & $\begin{array}{l}\text { Need to improve the } \\
\text { quality of the eggs so } \\
\text { seed }\end{array}$ & 180 & $\begin{array}{l}\text { Encourage increased } \\
\text { hatchery performance }\end{array}$ & 40 & $\begin{array}{l}\text { Socialization quality } \\
\text { seed and engineering } \\
\text { aspects of the } \\
\text { technology }\end{array}$ & 220 \\
\hline 5 & $\begin{array}{l}\text { Hatchery always receive } \\
\text { good quality eggs }\end{array}$ & 80 & $\begin{array}{l}\begin{array}{l}\text { Accuracy of the } \\
\text { hatcheries } \\
\text { always high }\end{array} \\
\end{array}$ & 170 & $\begin{array}{l}\text { Strengthening efforts } \\
\text { to produce quality seed }\end{array}$ & 30 & $\begin{array}{l}\text { The application of } \\
\text { environmentally } \\
\text { friendly technologies }\end{array}$ & 200 \\
\hline FA & THREATH & SCORE & STRATEGY S-T & SCORE & STRATEGY W-T & SCORE & $\begin{array}{l}\text { COMPILATION SWT } \\
\text { STRATEGY }\end{array}$ & SCORE \\
\hline 1 & $\begin{array}{l}\text { Confidence high } \\
\text { spawner often careless }\end{array}$ & -60 & $\begin{array}{l}\text { Need understanding of } \\
\text { quality management } \\
\text { for pemijah }\end{array}$ & 30 & $\begin{array}{l}\text { Strengthening the } \\
\text { performance of good } \\
\text { breeding practices } \\
\text { applicable }\end{array}$ & -120 & $\begin{array}{l}\text { Applying recording in } \\
\text { good } \\
\text { practices }\end{array}$ & -90 \\
\hline 2 & $\begin{array}{l}\text { Spawner no longer pay } \\
\text { attention to kinship } \\
\text { broodstock }\end{array}$ & -50 & $\begin{array}{l}\text { Need precision } \\
\text { observe broodstock if } \\
\text { appropriate documents }\end{array}$ & 50 & $\begin{array}{l}\text { Need precision observe } \\
\text { broodstock if } \\
\text { appropriate documents }\end{array}$ & -100 & $\begin{array}{l}\text { Training continued to } \\
\text { recognize the quality } \\
\text { of a good broodstock }\end{array}$ & -50 \\
\hline 3 & $\begin{array}{l}\text { There is still a decline in } \\
\text { the quality of the } \\
\text { broodstock as a result of } \\
\text { handling }\end{array}$ & -40 & $\begin{array}{l}\text { Preparation of } \\
\text { pre-spawning holding } \\
\text { to be really careful }\end{array}$ & 30 & $\begin{array}{l}\text { Strengthening the } \\
\text { application record data } \\
\text { on all actors }\end{array}$ & -120 & $\begin{array}{l}\text { Maintain commitment } \\
\text { and performance } \\
\text { consistency seeding }\end{array}$ & -90 \\
\hline 4 & $\begin{array}{l}\text { Spawner perform a } \\
\text { variety of ways to seed } \\
\text { 'good' }\end{array}$ & -50 & $\begin{array}{l}\text { Spawner encouraged } \\
\text { to issue quality seed }\end{array}$ & 40 & $\begin{array}{l}\text { Strengthening business } \\
\text { ethics based breeder } \\
\text { quality }\end{array}$ & -100 & $\begin{array}{l}\text { Breeder commitment } \\
\text { in determining the } \\
\text { quality of the } \\
\text { broodstock }\end{array}$ & -60 \\
\hline 5 & $\begin{array}{lr}\text { Treatment } & \text { breeder } \\
\text { creates } & \text { many } \\
\text { engineering seed } & \\
\end{array}$ & -40 & $\begin{array}{l}\text { Minimize production } \\
\text { engineering with } \\
\text { regulation }\end{array}$ & 50 & $\begin{array}{l}\text { Minimize production } \\
\text { engineering } \\
\text { regulation }\end{array}$ & -90 & $\begin{array}{l}\text { The application of } \\
\text { environmentally } \\
\text { friendly technologies }\end{array}$ & -40 \\
\hline & & & $\begin{array}{l}\text { COMPILATION } \\
\text { STRATEGY SOT }\end{array}$ & SCORE & $\begin{array}{l}\text { COMPILATION } \\
\text { STRATEGY WOT }\end{array}$ & SCORE & SWOT STRATEGY & SCORE \\
\hline & & & $\begin{array}{l}\text { Breeder commitment } \\
\text { and consistent record } \\
\text { process }\end{array}$ & 210 & $\begin{array}{l}\text { Habituation } \\
\text { implementation of } \\
\text { good breeding } \\
\text { practices }\end{array}$ & -90 & $\begin{array}{l}\text { Storing data track } \\
\text { record of spawning }\end{array}$ & 240 \\
\hline & & & $\begin{array}{l}\text { Need precision } \\
\text { observe broodstock if } \\
\text { appropriate documents }\end{array}$ & 250 & $\begin{array}{l}\text { Need precision observe } \\
\text { broodstock if } \\
\text { appropriate documents }\end{array}$ & -50 & $\begin{array}{l}\text { Document the origin } \\
\text { of the broodstock } \\
\text { displayed publicly }\end{array}$ & 400 \\
\hline & & & $\begin{array}{l}\text { Seed production pond } \\
\text { needs appropriate } \\
\text { planning time }\end{array}$ & 180 & $\begin{array}{l}\text { Commitment and } \\
\text { consistency in } \\
\text { recording (for tracer) }\end{array}$ & -120 & $\begin{array}{l}\text { The publication of } \\
\text { the data tracer by } \\
\text { breeder }\end{array}$ & 120 \\
\hline & & & $\begin{array}{l}\text { Breeder issued } \\
\text { integrity seed quality }\end{array}$ & 220 & $\begin{array}{l}\text { Avoid the use of } \\
\text { chemicals } \\
\text { antibiotics }\end{array}$ & -60 & $\begin{array}{l}\text { Quality assurance } \\
\text { through data search } \\
\text { seed from the } \\
\text { broodstock }\end{array}$ & 320 \\
\hline & & & $\begin{array}{l}\text { Stimulating the } \\
\text { production of high } \\
\text { quality natural }\end{array}$ & 220 & $\begin{array}{l}\text { Familiarize production } \\
\text { system with probiotics }\end{array}$ & -60 & $\begin{array}{l}\text { Issuance of letters of } \\
\text { guarantee seed green }\end{array}$ & 320 \\
\hline
\end{tabular}

SWOT analysis Balanced Score Card (Table 3) found 5 traceability implementation strategy following tiger shrimp hatchery business priorities as follows: 
1. Build a data security system search origins stem (120).

2. Determination of price incentives seed from the broodstock-grade (80).

3. Broodstock must be certified origin ( $\mathrm{COO}=$ Certificate Of Origin) (80).

4. The publication of data by breeder seed tracer (40).

5. Storing data track record of spawning (40).

The five step strategy as well as recommendations for government action with its associates and business people seeding. Efforts are offset commitment, consistency and fairness in implementing traceability in business lines and seed shrimp broodstock; believed to be able to lift the shrimp business back on all fronts that will ultimately promote national shrimp production comes from the seed breeders in the country.

SWOT analysis Balanced Score Card (Table 4) found 5 traceability implementation strategy follows vannamei shrimp hatchery business priorities as follows:

1. Document the origin of the broodstock displayed openly (400).

2. Seed quality assurance through data search from the broodstock (320).

3. Issuance of letters of guarantee seed green (320).

4. Storing data track record of spawning process (240).

5. The publication of the data tracer by spawner (120).

The results of the comparative table shows that the implementation of traceability in vannamei shrimp hatchery business is now more important priority than the shrimp hatchery business.

Production of vannamei shrimp in Indonesia is much larger than the black tiger shrimp. Needs to vannamei shrimp seed it much higher than tiger shrimp. In order to support the achievement of shrimp vannamei productivity targets; that quality of implementation traceability on vannamei shrimp is a major priority. The majority of farmers stated that the price of seeds is not a major consideration in farming (Caporale, V., et all. 2001; Kosim, et all. 2007; Nurdjana. 2008).

Table 5. Comparison Traceability Implementation Priorities Breeding Business

\begin{tabular}{|c|c|c|c|}
\hline \multicolumn{2}{|l|}{ TIGER SHRIMP } & \multicolumn{2}{|l|}{ VANNAMEI SHRIMP } \\
\hline $\begin{array}{l}\text { Build a data security system search } \\
\text { origins stem }\end{array}$ & 120 & $\begin{array}{l}\text { Document the origin of the } \\
\text { broodstock displayed openly }\end{array}$ & 400 \\
\hline $\begin{array}{l}\text { Determination of price incentives seed } \\
\text { from the broodstock-grade }\end{array}$ & 80 & $\begin{array}{l}\text { Seed quality assurance through data } \\
\text { search from the broodstock }\end{array}$ & 320 \\
\hline $\begin{array}{l}\text { Broodstock must be certified origin } \\
\text { (Certificate Of Origin) }\end{array}$ & 80 & $\begin{array}{l}\text { Issuance of letters of guarantee seed } \\
\text { green }\end{array}$ & 320 \\
\hline $\begin{array}{l}\text { The publication of data by breeder seed } \\
\text { tracer }\end{array}$ & 40 & $\begin{array}{l}\text { Storing data track record of spawning } \\
\text { process }\end{array}$ & 240 \\
\hline Storing data track record of spawning & 40 & $\begin{array}{l}\text { The publication of the data tracer by } \\
\text { spawner }\end{array}$ & 120 \\
\hline
\end{tabular}

Source: Analysis Data (2012) 
LOGO

Dates

Kepada Yth.

NO. NOTA

di

TRACER CODE:

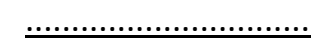

\begin{tabular}{|l|l|l|l|l|}
\hline NO & NAMELY & UNITS & PRICE (Rp) & TOTAL (Rp) \\
\hline & & & & \\
\hline & & & & \\
\hline & & & & \\
\hline & & & & \\
\hline
\end{tabular}

Says:

$\begin{array}{lll}\text { Technician } & \text { Accounting } & \text { Customer }\end{array}$

Figure 1. Specimen Nota Traceability

Determination of tracer code to record the capture area of the broodstock and technically seeding practices. Preparation numeric code that registers will be included in the memorandum of sale of seed should be done jointly by the Government and the Association of seeding. Standards and sanctions, can be played by the supplier, and cold storage. Supplier has the right to buy at the local market price for non-tracer prawn cold storage while the right to refuse shrimp seed sales do not have a memorandum of traceability.

Based on these simple sales memorandum format, traceability could have been implemented with accurate and contains in-depth search. The code reflects the location tracer hatchery / backyard in District / City + catcher + spawner + breeder + shrimp brokers whole or in part. In the memorandum contained a company logo (symbol A) following the registration number that shows companies or individuals who run a seed business. Memorandum and the date may contain internal information about the technical aspects are reinforced by information based on records technician for seeding lasts includes tracing up to the broodstock identity number like spawning and hatchery. Technicians and Managers responsible for information resources in case of food safety incidents, Accounting for the purposes of the company, while the buyer is a data search to find a farmer or even seed traders.

In the event that a broodstock shrimp business comes from imports, the tracer code catcher broodstock and breeder may contain information search origin imported interpreted code or code numbers importers import documents. 


\section{Conclusion}

Initiation of tracer at the level of seed documents is an important step that should be realized in the framework in implementing the traceability. This is in accordance with Article 5 point e the Minister of Marine Affairs and Fisheries No. 15 Year 2011; then document tracer in the form of a memorandum is a form of concrete technical implementation seeding was implemented GBP. Oversight functions should be performed by government personnel as well as Article 1, paragraph 8, 9, 11, 12, 14 and 15, and Chapter III Article 11, 12, 13 and 14; in fact do. Benefits of initiation document tracer can be directly enjoyed by the share holders to consumers and exporters.

Initiation tracer document should be designed in standard form documents and flexibly defined circulation with an umbrella memorandum of law in the form of technical guidelines seed marketing. Monitoring circulation memorandum supervised by government staff in the area. Another benefit of implementing traceability through the documents in the form of a memorandum of tracer marketing is obtaining accurate data, continuous updating, as well as the creation of a system of reporting and to naturally seed business.

The principle of substance in the document should contain information such as tracer:

1. Code of the city / county where seed production in East Java two-digit numbers or letters,

2. Code catcher (fishing base fishermen) or the importer holding one digit letters or numbers,

3. Code of broodstock shrimp breeder also one digit letters or numbers,

4. Spawner also one digit code letter or number,

5. Breeder Code (hatchery or backyard) two-digit numbers or letters,

6. Penggelondong as breeder two-digit code numbers or letters,

7. Pendeder as breeder code (in terms of the involvement of brokers seed, specifically the government officials or local seed associations can be formed to assist the formulation of tracer code for brokers, so the broker also responsible in terms of establishing traceability of shrimp Indonesia) maximum three-digit combination of numbers and / or letters.

Seventh tracer codes are compiled by systematic trace defined above is information directly related to traceability of data in document / memorandum of sale. Thus, in case of food safety incidents that allegedly directly or indirectly related to the performance of seeding, the source of the problem can be found and determined accurately.

\section{Acknowledgments}

Prof. Dr. Ir. Kamiso, H.N., M.Sc. (Gajah Mada University); Dr. Ir. Nazori Djazuli, M.Sc. (Director of Quality, Ministry of Marine Affairs and Fisheries); Dr. Ir. Hardoko, MS. (Brawijaya University); Partono (hatchery entepreneurs); Ir. Sardjono Budi Santoso (CEO of hatchery and animal healthy distributor) and Ir. Junaedi Ispinanto (Secretary General of ASPAKINDO). 


\section{References}

Anonymous. (2008). Department of Marine Fisheries National Shrimp Production Runway. Department of Marine Fisheries. Jakarta.

Caporale, V., Giovannini, A., Di Francesco, C., \& Calistri, P. (2001). Importance of the Traceability of Animals and Animal Products in Epidemiology. Rev. Sci. Tech. Off. Int. Epiz.; Instituto Zooprofilattico Sperimentale dell'Abruzzo e del Molise 'G. Caporale, Via Campo Boario, 64100 Teramo. Italy. Page 1 of 7 (372 pages)

Dahuri, R. (2004). Development and Aquaculture Development Indonesia Hopes for the Future. Symposium on Development and Innovation of Science and Technology of Aquaculture. Indonesian Aquaculture Society Annual Report. Semarang.

Kosim, H. M., Elin A., \& Ady, S. (2007). Traceability Application Handbook for Process Black Tiger Shrimp and Vannamei shrimp. CV. Ali Ridho Fees Through Group Process in PT. Kemilau Bintang Timur-Makasar. Sidoarjo.

Nurdjana, M. L. (2008). Featured Shrimp Fishery Exports. Voi ce Updates. Jakarta.

Caswell, J. A. (1998). How labeling of safety and process attributes affect markets for food. Agric Resour Econ Rev, Oct, 151-158.

[CEN] European Committee for Standardization. (2002). Traceability of fishery productsspecifications of the information to be recorded in captured fish distribution chains. CEN workshop agreement. CEN, Brussels, Belgium. Available from: http:/ /193.156.107.66/ff/po/EUTrace/WGCaptured/WGC_StandardFinal.doc. Accessed 2012 December 14.

Hashimoto, T., Tanaka, K., \& Niwa, H. (2003). Trial of farmed fish traceability in Japan. 1st Joint Trans-Atlantic Fisheries Technology Conference-TAFT 2003; 2003 June 11- 4; Reykjavik.

Hernandez, MRP. (2001). Study of the quality management system and product traceability in a fish processing company. Final Project 2001. United Nations Univ, Fisheries Training Programme. United Nations Univ: Reykjavik, Iceland. Available from: http://www.unuftp.is/proj01/MariaRitaPRF.pdf. Accessed 2013 January 10.

Loureiro, ML, \& McCluskey, JJ. (2000). Assessing consumer response to protected geographical identification labeling. Agribusiness, 16(3), 309-20. http://dx.doi.org/10.1002/1520-6297(200022)16:3<309::AID-AGR4>3.0.CO;2-G

Thompson, M, Sylvia, G, \& Morrissey, MT. (2003). Seafood traceability in the U.S. Annual Meeting of the Inst. of Food Technologists, 2003 July 12-6; Chicago, Ill.

Westgren, RE. (1999). Delivering food safety, food quality, and sustainable production practices: the label rouge poultry system in France. Am J Agric Econ, 81(5), 1107-1111. http://dx.doi.org/10.2307/1244092 


\section{Copyright Disclaimer}

Copyright reserved by the author(s).

This article is an open-access article distributed under the terms and conditions of the Creative Commons Attribution license (http://creativecommons.org/licenses/by/3.0/). 